Acta Universitatis Lodziensis

\title{
The spread of alien species along the touristic routes of the Słowiński National Park
}

\author{
ANASTAZJA KRZYŻANOWSKA ${ }^{1}$, PRZEMYSŁaW PIOTR TOMCZYK ${ }^{1 *}$, PAUlina \\ PRUSZKOWSKA-PRZYBYLSKA ${ }^{2}$, KATARZYNA MARIA ZIELIŃSKA ${ }^{1}$ \\ ${ }^{1}$ Department of Geobotany and Plant Ecology, Faculty of Biology and Environmental Protection, \\ University of Lodz, Banacha 12/16, 90-237 Łódź \\ ${ }^{2}$ Department of Anthropology, Faculty of Biology and Environmental Protection, University of Lodz, \\ Banacha 12/16, 90-237 Łódź \\ E-mail: przemyslaw.tomczyk@biol.uni.lodz.pl
}

\section{AbSTraCT}

Touristic routes have a great meaning for the spread of alien species through the protected areas like national parks. The aim of the study was to assess the spread of the chosen species along the different kinds of touristic routes of the Słowiński National Park and asphalt roads lying in the direct vicinity of the Park, in its protective zone. The presence of 108 localities of eight alien species were recorded (Padus serotina, Quercus rubra, Acer negundo, Robinia pseudoacacia from woody species and Conyza canadensis, Impatiens parviflora, Juncus tenuis and Oxalis fontana from herbaceous plants). The localities of the woody plants were found in areas where they were formerly deliberately planted or near routes leading to such areas. All of the analysed woody plants can be the source of ecological threat and should be actively removed. Interestingly, regarding herbaceous plants, the species which according to literature are not a threat to untransformed habitats - Juncus tenuis and Oxalis fontana - were noted quite commonly. Their populations should be monitored. The populations of Impatiens parviflora, classified to the IV class of invasiveness and Conyza canadensis, which can invade sand dunes, should be destroyed as soon as possible till they occupy small areas.

KEY WORDS: invasive species, anthropopression, protected areas, synanthropic plants

\section{Introduction}

Touristic routes are the paths and roads used for hiking, biking or even driving through the areas of special touristic value. The very important feature of touristic routs is their linear character what means very big ratio of their length to width. This is the reason why they can act as a kind of ecological corridors (Forman et al. 2003, Lugo \& Gucinski 2000). Despite usually small area of the touristic routes in the context of the whole protected area their impact can be meaningful. 
Roads are a type of habitat well known for the significantly bigger number of invasive plant species in comparison to the surrounding habitats (Damschen et al. 2014, Flory \& Clay 2006, Flory \& Clay 2009, Parendes \& Jones 2000, Pauchard \& Alaback 2006, Rooney 2005, Watkins et al. 2003). Transport is to a large extent associated with an unintentional transfer of propagules and roadsides function for many invasive plant species as a prime habitats. It means that roadside populations are the source ones from which species spread into seminatural or natural plant communities (Joly et al. 2011, Rooney 2005). The alien species usually concentrate along roads because the roads create disturbed habitats in which the competition from native species is lower. In forests narrow paths of open habitats also facilitate the dispersion of seeds, sometimes over very long distances (McKinney 2002).

It is widely believed that the ecological role of roads depends on the intensity of human traffic. Tourism is one of the factors generating the traffic around the world and increasing the phenomenon of alien species spreading (Weber 2000). The aim of this article was to present the role of different kinds of routes in the Słowiński National Park, from the small paths used for hiking to the asphalt roads (Figure 1). The Park is a huge attraction for tourists because of the beautiful beaches at the seaside. Thus the most popular are the trails leading to the seashore, however those going through the belt of moving dunes or to the old lighthouse in Czołpino are very popular also. The number of tourists visiting the Park each year is difficult to determine, but it is circa 275000 people, what means

\section{Materials and methods}

The Słowiński National Park (pol. Słowiński Park Narodowy, SPN) is located in the north part of the Poland, on
12 people per one ha (data from 2008) (Partyka 2010). Touristic traffic within the Park is not distributed evenly. The total length of touristic routes is $144.3 \mathrm{~km}$ (Partyka 2010), but they are very diversified. Many of them are up to three meters wide and used by a large number of tourists getting to the seashore. Among them, the hardened road leading from Łeba to the interior of the Park, where the movement of electric vehicles is allowed, draws attention. It gives possibility not only to get closer to the seashore and the belt of moving dunes, but also enables setting out on a boat trip on Lebsko Lake and to see the military exhibition of rocket launcher. However very long fragments of touristic routes in the Park are used by few tourists ready for walking trips covering many kilometers or by bikers. In the analysis we included different kinds of routes crossing the National Park and also the asphalt roads typical for Łeba and other urbanized areas lying in the direct vicinity of the Park. Four woody and four herbaceous species of alien plants were selected to the analysis. Among these taxa there were the ones considered to be dangerous for native plant biodiversity as well as the ones that accordingly to the literature have not been regarded as invasive yet.

The aims of the study were:

- to evaluate the spread of the chosen alien species along the different kinds of touristic routes going through the Słowiński National Park and its protective zone;

- to evaluate the necessity of the active removal of specimens of these species.

the coast of the Baltic Sea. In the area of the Park there is well preserved system of zonal vegetation associated with a seashore. Close to the sea a narrow zone of ephemeral, pioneering dune flora 
involving halophytic plants is located. Beyond, there is a zone of white dune plant communities, further in the hinterland, there is a zone of gray dunes and finally a wooded area. The forest phytocoenoses of the National Park consist of birch and alder stands characteristic for swamp and alluvial sites, deciduous stands of hornbeam, beech, birch and oak trees, and coastal and inland pine stands. In the SPN there are also two big eutrophic lakes: Gardno and Łebsko, and several smaller lakes and fens with typical for such sites natural vegetation (Piotrowska 1997, Wojterski 1979).

Figure 1. The area of the Słowiński National Park with different kinds of routes taken to the analysis (I - IV the route categories described in the text).

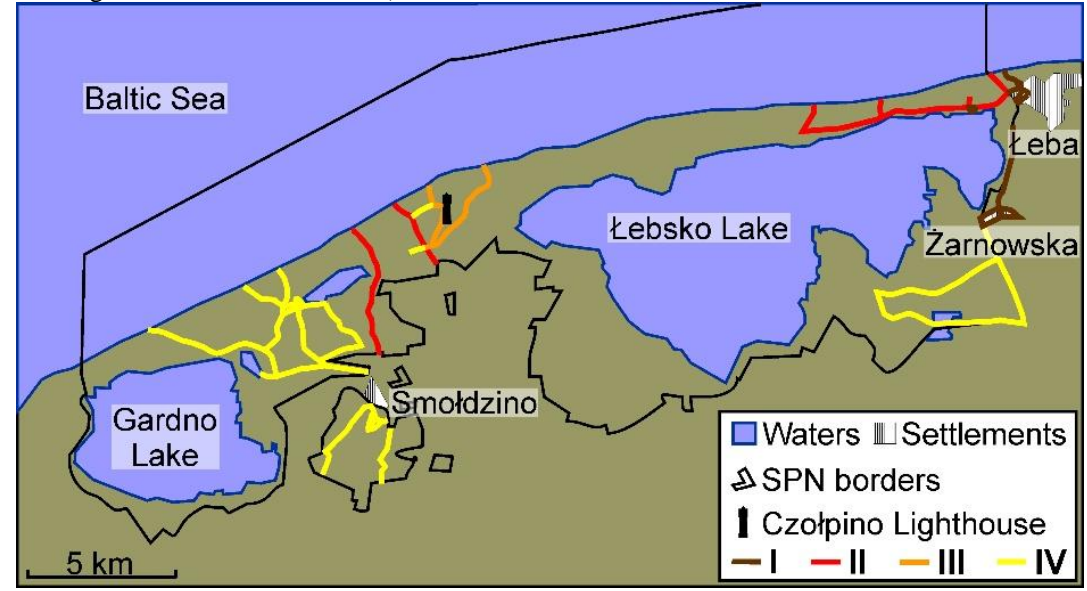

The research was conducted in July in the years 2013 and 2014, within the framework of the project "Inventory of the alien plant species along the touristic routes of the Słowiński National Park" led by the Botany Section of The Biological Student Association of University of Lodz. The study included four species of woody plants brought to Poland for commercial purposes and for gardening: Padus serotina Ehrh., Quercus rubra L., Acer negundo L. and Robinia pseudoacacia L. We investigated both the mature trees and seedlings. Another four species of herbaceous plants unintentionally dragged to the country or escaped from botanical gardens were chosen: Conyza canadensis (L.) Cronquist, Impatiens parviflora DC., Juncus tenuis Willd., Oxalis fontana L. The characteristic features of the chosen species are presented in Table 1 . The occurrence of the mentioned species was noted alongside the touristic routes of four different categories:

I - the asphalt roads lying in the direct vicinity of the Park (in its protective zone) or constituting the border of the Park these roads are connected with the routes coming directly through the Park;

II - the shortest routes to the beach, with the parking areas lying at the Park borders - these paths are used by a large number of people interested in the rest on the seashore;

III - the routes leading to the tourist attractions of the Park (route through the moving dunes or to the old lighthouse) these are used by the tourists who are ready to take the effort of longer hike to see some interesting places from different point of view;

IV - the long routes leading through the forests and near lakes or lying in the 
south, less frequently visited by tourists, parts of the Park - these are used by few people enjoying long hiking, biking or by the local society.

We assumed that our categories represent different intensity of the human traffic. The length of the surveyed routes in the particular categories varied (I category: $9.5 \mathrm{~km}$; II: $13 \mathrm{~km}$; III: $5 \mathrm{~km}$; IV: $37 \mathrm{~km}$ ), but was representative for the Park (with the exception of the asphalt roads - these were analysed as a comparative sample at the east side of the Park protective zone). The routes chosen for the analysis are presented on Figure 1.

The occurrence of the chosen alien species was noted with the standard GPS device (application GPS Essentials uploaded to Samsung Galaxy Tab 8.9) so their accuracy (usually about 25 meters) decided about placing the next GPS point. In that way we recorded the separate localities of alien species specimens and we were setting the series of points if the population of the alien species was spread alongside the longer than 25 meters part of the route. In each point we were assessing the number of specimens or the surface area occupied by the species in square meters. The chosen method depended on the species and the degree of its spread (counting of specimens was possible in the case of the tree seedlings but in the case of such species like Juncus tenuis it would be ineffective). The following three-step scale of the population size evaluation was developed on the basis of the preliminary studies:

1 - one to three individuals of alien species,

2 - four to twenty individuals or covering smaller than one square meter,

3 - over twenty individuals or population covering at least one square meter.

The alien species which were noted during the studies grew directly on the routes or in the zone not wider than $1.5 \mathrm{~m}$ from the road surface.

The nomenclature of species was based on Mirek et al. (2002).

Table 1. The characteristic features of the chosen species

\begin{tabular}{|c|c|c|c|c|c|c|}
\hline Species & $\begin{array}{c}\text { The place of } \\
\text { origin }\end{array}$ & $\begin{array}{l}\text { Causes / way of } \\
\text { entering into Poland }\end{array}$ & $\begin{array}{l}\text { Main properties of species } \\
\text { conducive to its invasion }\end{array}$ & $\begin{array}{l}\text { Native habitats } \\
\text { threatened by } \\
\text { invasive species }\end{array}$ & $\begin{array}{l}\text { Ways to combat } \\
\text { (safe for the } \\
\text { environment) }\end{array}$ & $\begin{array}{c}\text { Category of } \\
\text { invasiveness } \\
\text { (Tokarska- } \\
\text { Guzik } \text { et al. } \\
\text { 2012) }\end{array}$ \\
\hline Acer negundo & North America & $\begin{array}{c}\text { Planted as a roadside } \\
\text { tree and in parks, also } \\
\text { promoted as a } \\
\text { melliferous tree and used } \\
\text { for the restoration of } \\
\text { degraded land } \\
\text { (Packiewicz et al. 2006, } \\
\text { Frączek et al. } 2009 \text { ). }\end{array}$ & $\begin{array}{l}\text { Species with high resistance to } \\
\text { high and low temperatures, } \\
\text { drought and chemical } \\
\text { contamination of the soil. It has } \\
\text { light fruits that are spread by } \\
\text { wind and water (Packiewicz et } \\
\text { al. 2006, Frączek et al. 2009, } \\
\text { Bijak et al. 2014, Danielewicz } \\
\text { \& Wiatrowska 2014). }\end{array}$ & $\begin{array}{l}\text { willow-poplar } \\
\text { forests (Salici- } \\
\text { Populetum) } \\
\text { (Mędrzycki 2014) }\end{array}$ & $\begin{array}{l}\text { The most common } \\
\text { method is felling } \\
\text { trees at the base of } \\
\text { the root collar } \\
\text { (Credit Valley } \\
\text { Conservation 2011, } \\
\text { Mędrzycki 2014). }\end{array}$ & IV \\
\hline Padus serotina & $\begin{array}{l}\text { North and } \\
\text { South America }\end{array}$ & $\begin{array}{l}\text { Due to the rapid and } \\
\text { luxuriant growth it has } \\
\text { been used in the } \\
\text { plantings in the forests } \\
\text { (Namura-Ochalska } \\
\text { 2012). }\end{array}$ & $\begin{array}{l}\text { Dispersed by birds, especially } \\
\text { starlings (Krzysztofiak \& } \\
\text { Krzysztofiak 2015). It has } \\
\text { ability of very intense vegetative } \\
\text { propagation and strong } \\
\text { competitiveness due to } \\
\text { allelopathy (Robakowski \& } \\
\text { Bielinis 2011). }\end{array}$ & $\begin{array}{c}\text { Forest } \\
\text { communities, } \\
\text { mostly old } \\
\text { acidophilous oak } \\
\text { woods (Tokarska- } \\
\text { Guzik et al. } 2012 \text { ) }\end{array}$ & $\begin{array}{l}\text { The easiest way is } \\
\text { to eliminate the } \\
\text { juveniles that can be } \\
\text { pull out by hand. } \\
\text { For mature } \\
\text { specimens the most } \\
\text { effective treatment } \\
\text { is grubbing } \\
\text { individuals } \\
\text { (Namura-Ochalska } \\
\text { 2012). }\end{array}$ & IV \\
\hline
\end{tabular}


Table 1. The characteristic features of the chosen species (cont.)

\begin{tabular}{|c|c|c|c|c|c|c|}
\hline Species & $\begin{array}{c}\text { The place of } \\
\text { origin }\end{array}$ & $\begin{array}{l}\text { Causes / way of } \\
\text { entering into Poland }\end{array}$ & $\begin{array}{l}\text { Main properties of species } \\
\text { conducive to its invasion }\end{array}$ & $\begin{array}{l}\text { Native habitats } \\
\text { threatened by } \\
\text { invasive species }\end{array}$ & $\begin{array}{l}\text { Ways to combat } \\
\text { (safe for the } \\
\text { environment) }\end{array}$ & $\begin{array}{l}\text { Category of } \\
\text { invasiveness } \\
\text { (Tokarska- } \\
\text { Guzik et al. } \\
\quad \text { 2012) }\end{array}$ \\
\hline Quercus rubra & $\begin{array}{c}\text { Eastern and } \\
\text { central USA } \\
\text { and south- } \\
\text { central Canada }\end{array}$ & $\begin{array}{l}\text { Species grown for wood } \\
\text { (has less knots in wood } \\
\text { than native species) and } \\
\text { as an ornamental tree } \\
\text { (Kuc et al. 2012). }\end{array}$ & $\begin{array}{l}\text { Resistant to pollution, drought } \\
\text { and frost. The species heavily } \\
\text { shadows the ground, releases } \\
\text { allelopathic compounds and has } \\
\text { slowly decaying litter. It is } \\
\text { spread mainly by zoochory } \\
\text { (Danielewicz \& Wiatrowska } \\
\text { 2014). }\end{array}$ & $\begin{array}{l}\text { Quercus robur } \\
\text { forests and mixed } \\
\text { Quercus robur and } \\
\text { Pinus sylvestris } \\
\text { forests (Woziwoda } \\
\text { \& Obidziński } \\
\text { 2016) }\end{array}$ & $\begin{array}{l}\text { Cutting down } \\
\text { mature trees and } \\
\text { removing juveniles } \\
\text { for many years } \\
\text { (Tałałaj 2013). }\end{array}$ & IV \\
\hline $\begin{array}{c}\text { Robinia } \\
\text { pseudoacacia }\end{array}$ & $\begin{array}{l}\text { Appalachia } \\
\text { and Plateau } \\
\text { Ozark and } \\
\text { Ouachita } \\
\text { Mountains }\end{array}$ & $\begin{array}{l}\text { It is used for decorative } \\
\text { and economic reasons } \\
\text { (among others because } \\
\text { of its valuable wood, } \\
\text { melliferous flowers and } \\
\text { root system preventing } \\
\text { erosion) (Tokarska- } \\
\text { Guzik et al. 2015). }\end{array}$ & $\begin{array}{l}\text { It tolerates drought, air pollution } \\
\text { and soil salinity (Danielewicz \& } \\
\text { Wiatrowska 2014, } \\
\text { Kołaczkowska 2008). It releases } \\
\text { allelopathic compounds } \\
\text { (Tokarska-Guzik } \text { et al. } 2015 \text { ). }\end{array}$ & $\begin{array}{l}\text { Xeric and } \\
\text { calcareous } \\
\text { grasslands, dry } \\
\text { heaths, Euro- } \\
\text { Siberian steppe } \\
\text { woods with } \\
\text { Quercus sp. } \\
\text { (Tokarska-Guzik et } \\
\text { al. 2012) }\end{array}$ & $\begin{array}{l}\text { It is recommended } \\
\text { to cut down the } \\
\text { trees and then } \\
\text { eliminate all } \\
\text { growing shoots } \\
\text { (Obidziński \& } \\
\text { Woziwoda 2014). }\end{array}$ & IV \\
\hline $\begin{array}{l}\text { Conyza } \\
\text { canadensis }\end{array}$ & North America & Unknown / random & $\begin{array}{l}\text { One specimen can produce from } \\
\text { thousand to } 100 \text { thousands seeds } \\
\text { (Regehr \& Bazzaz 1979). The } \\
\text { seeds are very easily dispersed } \\
\text { by wind and water (Weaver } \\
\text { 2001). }\end{array}$ & $\begin{array}{l}\text { Meadows and sand } \\
\text { dunes (Thebaud \& } \\
\text { Abbott 1995) }\end{array}$ & Unexplored & I \\
\hline $\begin{array}{l}\text { Impatiens } \\
\text { parviflora }\end{array}$ & Central Asia & Unknown / random & $\begin{array}{c}\text { It produces a large number of } \\
\text { seeds (on average } 1-2 \text { thousand) } \\
\text { which are ejected under the } \\
\text { pressure of } 12 \text { atmospheres at a } \\
\text { distance of } 3-4 \text { meters (Sołtys- } \\
\text { Lelek \& Barabasz-Krasny } \\
\text { 2010). }\end{array}$ & $\begin{array}{l}\text { The vegetation of } \\
\text { river banks, } \\
\text { calcareous rocky } \\
\text { slopes, forests. } \\
\text { (Tokarska-Guzik et } \\
\text { al. 2012) }\end{array}$ & $\begin{array}{l}\text { Mechanic removal } \\
\text { of plants by pulling } \\
\text { them out before the } \\
\text { release of seeds or } \\
\text { mowing the young } \\
\text { specimens } \\
\text { (Adamowski \& } \\
\text { Bomanowska 2016). }\end{array}$ & IV \\
\hline Juncus tenuis & North America & Unknown / random & $\begin{array}{l}\text { The species is resistant to } \\
\text { trampling or running over. In } \\
\text { each capsule it produces an } \\
\text { average of } 270 \text { seeds which can } \\
\text { be carried by animals, people or } \\
\text { wheels (Richards 1943). }\end{array}$ & $\begin{array}{c}\text { Lowland hay } \\
\text { meadows } \\
\text { (Tokarska-Guzik et } \\
\text { al. 2012) }\end{array}$ & Unexplored & I \\
\hline Oxalis fontana & North America & Unknown / random & $\begin{array}{c}\text { It can spread vegetatively by } \\
\text { rhizomes (Hantz 1979, } \\
\text { Rutkowski 2006, Small 1896). }\end{array}$ & Lack & Unexplored & I \\
\hline
\end{tabular}

\section{Results}

The total number of 108 GPS points reflected the spread of the chosen alien species along the routes of the National Park. The number of the points for particular species and the most frequently recorded category of abundance (in parentheses) are as follow:

Conyza canadensis: 8 (3),
Impatiens parviflora: 10 (3),

Juncus tenuis: 23 (1),

Oxalis fonatana: 15 (2),

Padus serotina: 13 (1),

Quercus rubra: 27 (2),

Robinia pseudoacacia: 8 (1),

Acer negundo: 4 (1). 
The details relating to particular GPS points are included in the Appendix. The presence of the species was noted along almost each of the penetrated touristic routes in the whole area of the Park (Figure 2,3). The high concentration of the localities was connected with the asphalt roads in the protective zone of the
SPN (category I), besides we did not confirm the meaning of the road category. Along each of them we found the species in different categories of population size. Also each of analysed alien species was represented by populations of different size category, including those of the biggest abundance (Figure 2, 3).

Figure 2. Localisation of the GPS points corresponding to the chosen woody alien species localities in the area of the Słowiński National Park (marked by a dots, 1-3 - the categories of population size described in the text) and diagrams with the number of these GPS points noted along different kinds of routes (I-IV - the route categories described in the text).
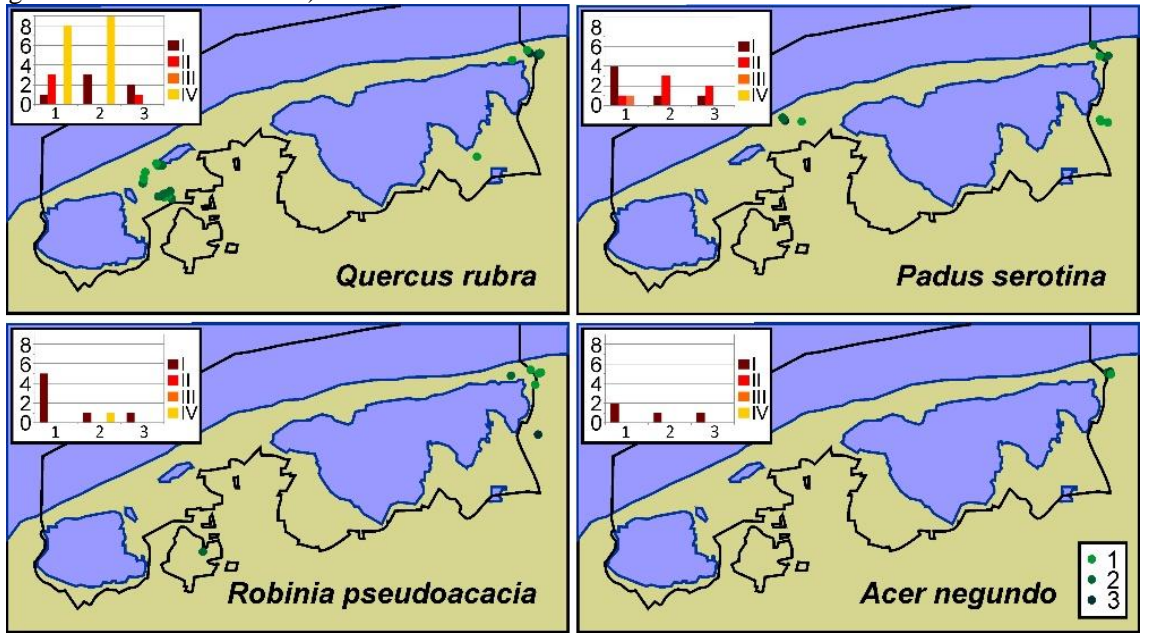

Figure 3. Localisation of the GPS points corresponding to the chosen herbaceous alien species localities in the area of the Słowiński National Park (marked by a dots, 1-3 - the categories of population size described in the text) and diagrams with the number of these GPS points noted along different kinds of routes (I-IV the route categories described in the text).
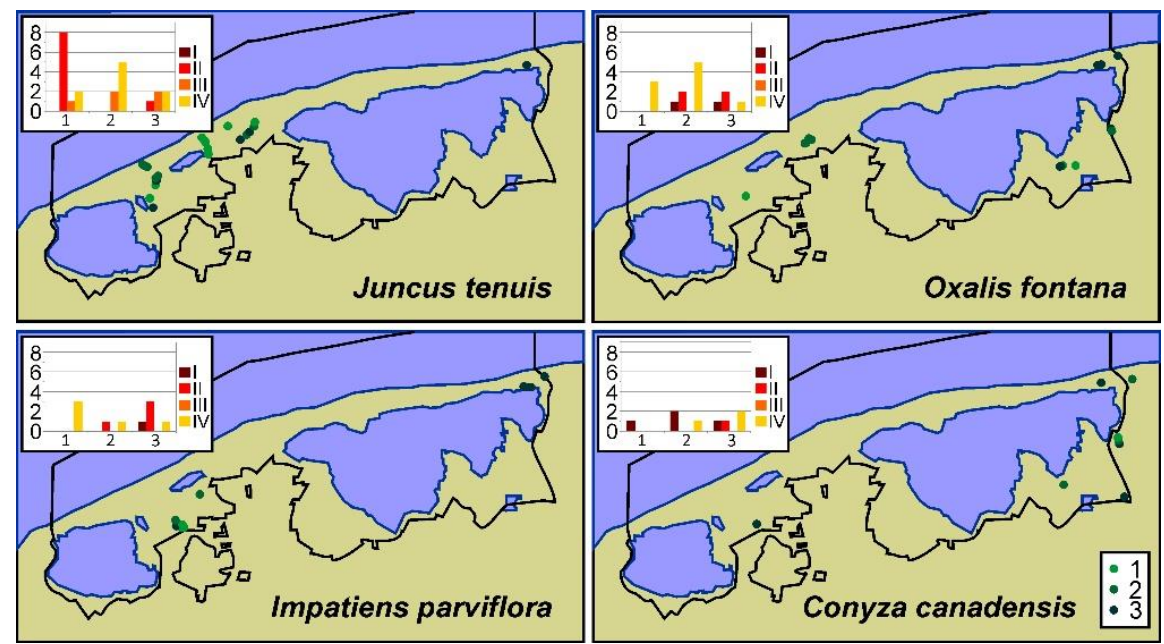


\section{Discussion}

The alien woody species were found more often along asphalt roads connecting towns or villages (I category). However, two of those species occurred also in the vicinity of touristic paths lying deep in the Park, we found a lot of young specimens of Quercus rubra and Padus serotina there. Those species are a residue of earlier forestry. They were deliberately introduced to the area, like to the other forest complexes in Poland (Gazda \& Augustynowicz 2012). Quercus rubra was found in the southern part of the Park, characterised by more fertile soils in comparison with the coastal area. Young seedlings were located in the vicinity of the mature trees. On the contrary, seedlings and young specimens of Padus serotina where found in places where the older individuals were not in sight. However those specimens grew near routes leading to the vicinity of the old military training area (to the north of Łebsko Lake), where the species was planted. Nowadays it spreads due to zoochory (Jagodziński et al. 2015). Thus the earlier plantations became a source populations for contemporary observed seedlings. On the borders of the National Park Quercus rubra and Padus serotina were observed near the human settlements. Similarly two other analysed tree species Acer negundo and Robinia pseudoacacia were connected with human settlements where they were planted (especially near Łeba). Our study did not confirm the importance of the road category for the spread of selected tree species, while the presence of the source populations was of crucial importance. The other authors confirm that the presence of specimens of the alien tree species in the vicinity of protected areas can be the real threat (e.g. Dajdok et al. 2007, Mędrzycki 2007, Namura-Ochalska 2012, Tałataj 2013).
Among all of the examined herbaceous species only Juncus tenuis was not present near the asphalt roads. This species was the most common from the analysed herbaceous plants and grow directly on the dirt roads and along them, very often in the small hollows in which the pools of stagnant water can occur after rainfalls. It was found most often on sandy soils on the roads leading to the sea. The others of the analysed alien herbaceous species occurred near roads of different categories, but in different parts of the SPN. For example Impatiens parviflora could not grow on very poor soils in the north part of the Park. So it was the presence of proper sites what was crucial for the spread of herbaceous plants. In this context special attention should be paid to Conyza canadensis. Although TokarskaGuzik et al. (2012) classified this taxon to the lowest category of invasiveness and Veawer (2001) described it as a ruderal species (colonizing abandoned agrocoenoses and other disturbed habitats), there are reports in literature that it can also grow in meadows and on sand dunes (Thebaud \& Abbott 1995). Because the moving dunes are one of the most valuable and unique features of the SPN, species which are able to occupy such habitats can be a real threat.

Each of the analyzed species was present in different classes of abundance, including the biggest one (over twenty individuals or population covering at least one square meter). That means that despite the chosen species were classified to different classes of invasiveness (Tokarska-Guzik et al. 2012), in the area of the SPN all of them have potential for successful spreading. We did not found the dependence between the type of touristic routes and the size of populations. It seems that the presence of the road is more important than its size. Along all of the investigated routes, even those rarely used, the alien species can be 
found and successfully spread. Other authors confirm that even small interference to the compactness of natural phytocoenoses may facilitate the alien species encroachment (Fornal-Pieniak 2011, Banaszek \& Szymczyk 2014).

\section{Conclusions}

Considering above, we postulate the active removal of the all of analysed woody species from the Park and its vicinity. Removal of mature trees and shrubs will reduce the number of emerging seedlings. In the case of herbaceous plants we postulate the destruction of patches of Impatiens parviflora and Conyza canadensis. The populations of these taxa are still relatively small, but they can function as sources of the future spreading. Their fast removal can reduce the threat and costs of possible future activities in the fight with alien species. Whereas in the case of very common, but classified to the lowest category of invasiveness species Juncus tenuis and Oxalis fontana, we propose monitoring them to determine whether they are expanding the area of occurrence. Because the sources of propagules of alien species (especially herbaceous) can be parking areas and places which are frequently chosen for the organised tourist trips, such areas should be regularly monitored.

\section{Acknowledgements}

We gratefully acknowledge the Authorities of the Słowiński National Park for any help and enabling of conducting field research. We also thank to all persons who provided us funds for the organization of scientific camps, during which the study was conducted: Rector of University of Lodz, prof. dr hab. Włodzimierz Nykiel; Dean of Faculty of Biology and Environmental Protection, prof. dr hab. Elżbieta Żądzińska; Director of Institute of Ecology and Environmental Protection, prof. dr hab. Piotr Frankiewicz and Chair of Department of Geobotany and Plant Ecology, prof. dr hab. Józef K. Kurowski.

\section{References}

Adamowski, W., Bomanowska, A. 2016. Niecierpek drobnokwiatowy Impatiens parviflora DC. In: Obidziński, A., Kołaczkowska, E. \& Otręba, A. (eds), Metody zwalczania obcych gatunków roślin występujących na terenie Puszczy Kampinoskiej, 1st edn, pp. 25-31. Kampinoski Park Narodowy.

Banaszek, J., Szymczyk, A. 2014. The influence of hum an impact on the diversity of plant species on the example of the landscape conservation protected area. Acta Geographica Silesiana, 17: 5-10.

Bijak, S., Czajkowski, M., Ludwisiak, Ł. 2014. Occurrence of black cherry (Prunus serotina Ehrh.) in the State Forests in Poland. Forest Research Papers, 75: 359-365.

Credit Valley Conservation. 2011. Methods to control invasive species. Mississauga, Ontario, Canada.

http://www.creditvalleyca.ca/wpcontent/upload s/2011/02/Methodsto ControlInvasives.pdf

Dajdok, Z., Krzysztofiak, A., Krzysztofiak, L., Romański, M., Śliwiński, M. 2007. Rośliny inwazyjne w Wigierskim Parku Narodowym.
Wydawnictwo Stowarzyszenia „Człowiek i Przyroda", Krzywe.

Damschen, E.I., Baker, D.V., Bohrer, G., Nathan, R., Orrock, J.L., Turner, J.R., Brudvig, L.A., Haddad, N.M., Levey, D.J., Tewksbury, J.J. 2014. How fragmentation and corridors affect wind dynamics and seed dispersal in open habitats. Proc Natl Acad Sci USA 111(9): 3484 3489.

URL: http://www.pnas.org/content/111/9/3484

Danielewicz, W., Wiatrowska, B. 2014. Inwazyjne gatunki drzew i krzewów w lasach Polski. Peckiana, 9: 59-67.

Flory, S.L., Clay, K. 2006. Invasive shrub distribution varies with distance to roads and stand age in eastern deciduous forests in Indiana, USA. Plant Ecology, 184: 131-141.

Flory, S.L., Clay, K. 2009. Effects of roads and forest successional age on experimental plant invasions. Biological Conservation, 142: 25312537.

Forman, R.T.T., Sperling, D., Bissonette, J.A., Clevenger, A.P, Cutshall, C.D., Dale, V.H., Fahrig, L., France, R., Goldman, C.R., Heanue, K., Jones, J.A., Swanson, F.J., Turrentine, T., 
Winter, T.C. 2003. Road ecology: science and solutions. Island Press, Washington.

Frączek, J., Mudryk, K., Wróbel, M. 2009. Klon jesionolistny Acer negundo L. - nowy potencjalny gatunek energetyczny. Acta Agrophysica, 14(2): 313-322.

Fornal-Pieniak, B. 2011. Impact of toursim on forest ecosystems in Ciężkowice district. Studia i Materiały CEPL w Rogowie R. 13, 3(28): 175180.

Gazda, A., Augustynowicz, P. 2012. Obce gatunki drzew w polskich lasach gospodarczych. Co wiemy o puli i o rozmieszczeniu wybranych taksonów? Studia i Materiały CEPL w Rogowie, 33(4): 53-71.

Hantz, J. 1979. Rodzaj Oxalis w Polsce. Fragmenta Floristica et Geobotanica, 25: 65-112.

Jagodziński, A.M., Dyderski, M. K., Rawlik, M., Banaszczak, P. 2015. Plantation of coniferous trees modifies risk and size of Padus serotina (Ehrh.) Borkh. invasion - Evidence from a Rogów Arboretum case study. Forest Ecology and Management 357: 84-94.

Joly, M., Bertrand, P., Gbangou, R.Y., White, M.C., Dubé, J., Lavoie, C. 2011. Paving the way for invasive species: road type and the spread of common ragweed (Ambrosia artemisiifolia). Environmental Management, 48(3): 514-522.

Krzysztofiak, L., Krzysztofiak, A. 2015. Zwalczanie niecierpka gruczołowatego Impatiens glandulifera w Wigierskim Parku Narodowym iw jego bezpośredniej otulinie. In: Krzysztofiak L., Krzysztofiak, A. (eds), Zwalczanie inwazyjnych gatunków roślin obcego pochodzenia-dobre i złe doświadczenia, Stowarzyszenie „Człowiek i Przyroda”, Krzywe, 75-88.

Kołaczkowska, E. 2008. Inwazje obcych gatunków roślin - problem naukowy i praktyczny. Przegląd Geograficzny, 80(1): 55-73.

Kuc, M., Piszczek, M., Janusz, A. 2012. Znaczenie dęba czerwonego w ekosystemie leśnym i rachunku ekonomicznym nadleśnictw Regionalnej Dyrekcji Lasów Państwowych w Katowicach. Studia i Materiały Centrum Edukacji Przyrodniczo-Leśnej, 14 (4): 152-159.

Lugo, A.E., Gucinski, H. 2000. Function, effects, and management of forest roads. Forest Ecology and Management, 133: 249-262.

McKinney, M.L. 2002. Influence of settlement time, human population, park shape and age, visitation and roads on the number of alien plant species in protected areas in the USA. Diversity and Distributions, 8(6): 311-318.

Mędrzycki, P., 2007. NOBANIS - Invasive Alien Species Fact Sheet - Acer negundo. From: Online Database of the European Network on Invasive Alien Species - NOBANIS <www.nobanis.org>. Date of access 01/08/2016.
Mędrzycki, P. 2014. Klon jesionolistny Acer negundo. W: Otręba A., Michalska-Hejduk D. (eds), Inwazyjne gatunki roślin w Kampinoskim Parku Narodowym i w jego sąsiedztwie. Kampinoski Park Narodowy.

Mirek, Z., Piękoś-Mirkowa, H., Zając, A., Zając, M. 2002. Flowering plants and pteridophytes of Poland. A checklist. W. Szafer Institute of Botany, Polihs Academy of Science, Kraków.

Namura-Ochalska, A. 2012. Walka z czeremchą amerykańską Padus serotina (Ehrh.) Borkh.Ocena skuteczności wybranych metod w Kampinoskim Parku Narodowym. Studia i Materiały CEPL w Rogowie, 33(4): 190-200.

Obidziński A, Woziwoda B. 2014. Klon jesionolistny Acer negundo. In: Otręba, A., Michalska-Hejduk, D (eds), Inwazyjne gatunki roślin w Kampinoskim Parku Narodowym i w jego sąsiedztwie. Kampinoski Park Narodowy.

Packiewicz, K., Wróbel, M., Wieczorek, T., Gilewska, M., Otremba, K. 2006. Charakterystyka wzrostu drzew klonu jesionolistnego, oliwnika wąskolistnego i robinii akacjowej na składowisku popiołów elektrownianych. Acta Scientiarum Polonorum, Formatio Circumiectus, 5 (1): 87-98.

Parendes, L.A., Jones, J.A. 2000. Role of light availability and dispersal in exotic plant invasion along roads and streams in the H.J. Andrews Experimental Forest, Oregon. Conservation Biology, 14: 64-75.

Partyka, J. 2010. Ruch turystyczny w polskich parkach narodowych. Folia Turistica 22: 9-24.

Pauchard, A., Alaback, P.B. 2006. Edge type defines alien plant species invasions along Pinus contorta burned, highway and clearcut forest edges. Forest Ecology and Management, 223: 327-335.

Piotrowska, H. 1997. Przyroda Słowińskiego Parku Narodowego. Bogucki Wydawnictwo Naukowe, Poznań-Gdańsk.

Richards, P. W. 1943. Juncus Macer. Journal of Ecology, 31(1), 51-59.

Robakowski, P., Bielinis, E. 2011. Competition between sessile oak (Quercus petraea) and black cherry (Padus serotina): Dynamics of seedlings growth. Polish Journal of Ecology, 59(2): 297-306.

Rooney, P.R. 2005. Distribution of ecologicallyinvasive plants along off-road vehicle trails in the Chequamegon National Forest, Wisconsin. The Michigan Botanist, 44: 178-182.

Rutkowski, L. 2006. Klucz do oznaczania roślin naczyniowych Polski niżowej. Wydawnictwo Naukowe PWN, Warszawa.

Sołtys-Lelek, A., Barabasz-Krasny, B. 2010. Ekspansja wybranych gatunków obcego pochodzenia we florze i szacie roślinnej Ojcowskiego Parku Narodowego (południowa 
Polska). Prądnik. Prace i Materiały Muzeum im. prof. Władysława Szafera, 20: 333-376.

Small, J. K. 1896. A Neglected Species of Oxalis and Its Relatives. Bulletin of the Torrey Botanical Club, 23(7), 265-269.

Tałałaj, I. 2013. Rośliny chronione i gatunki inwazyjne $\mathrm{w}$ dolinie Biebrzy - trwanie $\mathrm{i}$ migracja w zmieniających się warunkach środowiska. Przewodnik po sesji terenowej II Ogólnopolskiej Konferencji Naukowej „Różnorodność biologiczna - od komórki do ekosystemu. Rośliny i grzyby w zmieniających się warunkach środowiska. Oddział Białostocki Polskiego Towarzystwa Botanicznego, Białystok.

Thebaud, C., Abbott, R.J. 1995. Characterization of invasive Conyza species (Asteraceae) in Europe: Quantitative trait and isozyme analysis. American Journal of Botany, 82: 360-368.

Tokarska-Guzik, B., Bzdęga, K., Nowak, T., Urbisz, A., Węgrzynek, B., Dajdok, Z. 2015. Propozycja listy roślin gatunków obcych, które mogą stanowić zagrożenie dla przyrody Polski i Unii Europejskiej. Wydawnictwo Uniwersytetu Śląskiego, Katowice.
Tokarska-Guzik, B., Dajdok, Z., Zając, M., Zając, M., Urbisz, A., Danielewicz, W., Hołdyński, Cz. 2012. Rośliny obcego pochodzenia w Polsce ze szczególnym uwzględnieniem gatunków inwazyjnych. Generalna Dyrekcja Ochrony Środowiska, Warszawa.

Watkins, R.Z., Chen, J.Q., Pickens, J., Brosofske, K.D. 2003. Effects of forest roads on understory plants in a managed hardwood landscape. Conservation Biology, 17: 411-419.

Weaver, S.E. 2001. The biology of Canadian weeds, 115, Conyza canadensis. Canadian Journal of Plant Sciences, 81: 867-875.

Weber, E. 2000. Switzerland and the invasive plant species issue. Botanica Helvetica, 115: 77-81.

Wojterski, T. 1979. Mapa zbiorowisk roślinnych Słowińskiego Parku Narodowego. Zakład Kartografii i Geomatyki UAM, Poznań.

Woziwoda B., Obidziński A. 2016. Dąb czerwony Quercus rubra L. In: Obidziński, A., Kołaczkowska, E., Otręba, A. [eds], Metody zwalczania obcych gatunków roślin występujących na terenie Puszczy Kampinoskiej, pp. 89-97. Wydawnictwo BioDar, Izabelin-Kraków.

\section{Streszczenie}

Szlaki turystyczne mają wielkie znaczenie dla rozprzestrzeniania się obcych gatunków na obszarach chronionych, takich jak parki narodowe. Celem badań była ocena rozprzestrzeniania się wybranych gatunków wzdłuz różnego rodzaju szlaków turystycznych przebiegających przez Słowiński Park Narodowy oraz dróg asfaltowych leżących w bezpośrednim sąsiedztwie Parku, w jego otulinie. Stwierdzono obecność 108 stanowisk ośmiu obcych gatunków: Padus serotina, Quercus rubra, Acer negundo, Robinia pseudoacacia spośród gatunków drzewiastych oraz Conyza canadensis, Impatiens parviflora, Juncus tenuis i Oxalis fontana spośród roślin zielnych). Stanowiska roślin drzewiastych odnotowano na obszarach, gdzie wcześniej były celowo sadzone oraz wzdłuż szlaków prowadzących do takich obszarów. Wszystkie analizowane rośliny drzewiaste mogą być źródłem zagrożenia ekologicznego i powinny być aktywnie usuwane. W przypadku roślin zielnych, gatunki, które zgodnie z literaturą nie stanowią zagrożenia dla nieprzekształconych zbiorowisk roślinnych - Juncus tenuis i Oxalis fontana - notowano dość powszechnie. Ich populacje powinny być monitorowane. Populacje Impatiens parviflora, gatunku zaklasyfikowanego do IV klasy inwazyjności oraz Conyza canadensis, który zgodnie z literaturą może rozprzestrzeniać się na wydmach, powinny zostać zniszczone jak najszybciej, dopóki zajmują małe obszary. 


\section{Appendix}

The GPS points noted during the studies conducted in the years $2013-2014$. Abundance and road categories in accordance with the description in Material and methods.

\begin{tabular}{|c|c|c|c|}
\hline Species & Locality (GPS) & $\begin{array}{c}\text { Abundance } \\
\text { category }\end{array}$ & Road category \\
\hline \multirow{8}{*}{$\begin{array}{l}\text { Conyza canadensis }(\mathrm{L} .) \\
\text { Cronquist }\end{array}$} & 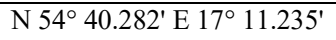 & 3 & IV \\
\hline & 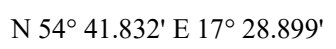 & 2 & IV \\
\hline & $\mathrm{N} 54^{\circ} 41.472^{\prime} \mathrm{E} 17^{\circ} 32.670^{\prime}$ & 3 & IV \\
\hline & $\mathrm{N} 54^{\circ} 45.455^{\prime}$ E $17^{\circ} 32.658^{\prime}$ & 2 & I \\
\hline & 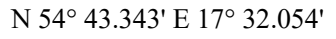 & 3 & I \\
\hline & $\mathrm{N} 54^{\circ} 43.450^{\prime} \mathrm{E} 17^{\circ} 31.778^{\prime}$ & 2 & I \\
\hline & 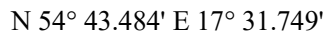 & 1 & I \\
\hline & $\mathrm{N} 54^{\circ} 45.297^{\prime}$ E $17^{\circ} 30.858^{\prime}$ & 3 & II \\
\hline \multirow[t]{10}{*}{ Impatiens parviflora $\mathrm{DC}$. } & 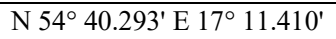 & 1 & IV \\
\hline & 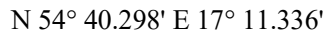 & 1 & IV \\
\hline & $\mathrm{N} 54^{\circ} 40.309^{\prime}$ E $17^{\circ} 11.048^{\prime}$ & 3 & IV \\
\hline & $\mathrm{N} 54^{\circ} 40.328^{\prime}$ E $17^{\circ} 11.135^{\prime}$ & 1 & IV \\
\hline & $\mathrm{N} 54^{\circ} 40.380^{\prime}$ E $17^{\circ} 10.929^{\prime}$ & 2 & IV \\
\hline & $\mathrm{N} 54^{\circ} 41.448^{\prime}$ E $17^{\circ} 12.521^{\prime}$ & 2 & II \\
\hline & $\mathrm{N} 54^{\circ} 45.680^{\prime}$ E $17^{\circ} 32.450^{\prime}$ & 3 & I \\
\hline & $\mathrm{N} 54^{\circ} 45.289^{\prime}$ E $17^{\circ} 31.359^{\prime}$ & 3 & II \\
\hline & $\mathrm{N} 54^{\circ} 45.274^{\prime}$ E $17^{\circ} 31.254^{\prime}$ & 3 & II \\
\hline & $\mathrm{N} 54^{\circ} 45.237^{\prime} \mathrm{E} 17^{\circ} 31.111^{\prime}$ & 3 & II \\
\hline \multirow[t]{14}{*}{ Juncus tenuis Willd. } & 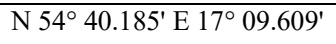 & 3 & IV \\
\hline & $\mathrm{N} 54^{\circ} 40.483^{\prime}$ E $17^{\circ} 09.442^{\prime}$ & 1 & IV \\
\hline & 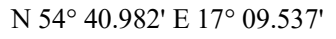 & 1 & IV \\
\hline & $\mathrm{N} 54^{\circ} 41.110^{\prime}$ E $17^{\circ} 09.594^{\prime}$ & 3 & IV \\
\hline & N 54 $41.216^{\prime}$ E $17^{\circ} 09.694^{\prime}$ & 2 & IV \\
\hline & $\mathrm{N} 54^{\circ} 41.359^{\prime}$ E $17^{\circ} 09.821^{\prime}$ & 2 & IV \\
\hline & $\mathrm{N} 54^{\circ} 41.518^{\prime} \mathrm{E} 17^{\circ} 09.131^{\prime}$ & 2 & IV \\
\hline & 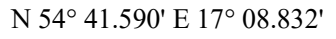 & 2 & IV \\
\hline & $\mathrm{N} 54^{\circ} 41.662^{\prime} \mathrm{E} 17^{\circ} 08.736^{\prime}$ & 2 & IV \\
\hline & $\mathrm{N} 54^{\circ} 41.978^{\prime}$ E $17^{\circ} 12.671^{\prime}$ & 1 & II \\
\hline & $\mathrm{N} 54^{\circ} 42.233^{\prime}$ E $17^{\circ} 12.572^{\prime}$ & 1 & II \\
\hline & $\mathrm{N} 54^{\circ} 42.321^{\prime}$ E $17^{\circ} 12.488^{\prime}$ & 1 & II \\
\hline & $\mathrm{N} 54^{\circ} 42.536^{\prime}$ E $17^{\circ} 12.345^{\prime}$ & 1 & II \\
\hline & 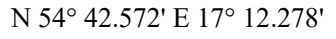 & 1 & II \\
\hline
\end{tabular}




\begin{tabular}{|c|c|c|c|}
\hline Species & Locality (GPS) & $\begin{array}{c}\text { Abundance } \\
\text { category }\end{array}$ & Road category \\
\hline \multirow[t]{9}{*}{ Juncus tenuis Willd } & $\mathrm{N} 54^{\circ} 42.617^{\prime}$ E $17^{\circ} 12.189^{\prime}$ & 1 & II \\
\hline & N $54^{\circ} 42.641^{\prime}$ E $17^{\circ} 12.144^{\prime}$ & 1 & II \\
\hline & $\mathrm{N} 54^{\circ} 42.648^{\prime}$ E $17^{\circ} 14.580^{\prime}$ & 3 & III \\
\hline & $\mathrm{N} 54^{\circ} 42.769^{\prime}$ E $17^{\circ} 14.752^{\prime}$ & 2 & III \\
\hline & $\mathrm{N} 54^{\circ} 42.887^{\prime}$ E $17^{\circ} 14.937^{\prime}$ & 3 & III \\
\hline & $\mathrm{N} 54^{\circ} 42.949^{\prime}$ E $17^{\circ} 13.722^{\prime}$ & 1 & II \\
\hline & $\mathrm{N} 54^{\circ} 43.089^{\prime}$ E $17^{\circ} 15.239^{\prime}$ & 2 & III \\
\hline & $\mathrm{N} 54^{\circ} 43.164^{\prime}$ E $17^{\circ} 15.275^{\prime}$ & 1 & III \\
\hline & $\mathrm{N} 54^{\circ} 45.270^{\prime}$ E $17^{\circ} 31.079^{\prime}$ & 3 & II \\
\hline \multirow[t]{15}{*}{$\overline{\text { Oxalis fontana } L .}$} & $\mathrm{N} 54^{\circ} 40.486^{\prime}$ E $17^{\circ} 10.589^{\prime}$ & 1 & IV \\
\hline & N $54^{\circ} 42.472^{\prime}$ E $17^{\circ} 13.897^{\prime}$ & 2 & IV \\
\hline & $\mathrm{N} 54^{\circ} 42.487^{\prime}$ E $17^{\circ} 13.942^{\prime}$ & 2 & IV \\
\hline & $\mathrm{N} 54^{\circ} 42.500^{\prime}$ E $17^{\circ} 14.015^{\prime}$ & 2 & IV \\
\hline & N $54^{\circ} 42.509^{\prime}$ E $17^{\circ} 14.071^{\prime}$ & 2 & IV \\
\hline & N $54^{\circ} 42.526^{\prime}$ E $17^{\circ} 14.098^{\prime}$ & 2 & II \\
\hline & N 54운.096' E $17^{\circ} 31.692^{\prime}$ & 3 & I \\
\hline & N $54^{\circ} 41.952^{\prime}$ E $17^{\circ} 29.575^{\prime}$ & 1 & IV \\
\hline & $\mathrm{N} 54^{\circ} 41.865^{\prime}$ E $17^{\circ} 28.875^{\prime}$ & 1 & IV \\
\hline & N $54^{\circ} 41.832^{\prime}$ E $17^{\circ} 28.899^{\prime}$ & 2 & IV \\
\hline & N $54^{\circ} 41.852^{\prime}$ E $17^{\circ} 28.834^{\prime}$ & 3 & IV \\
\hline & $\mathrm{N} 54^{\circ} 43.218^{\prime}$ E $17^{\circ} 31.570^{\prime}$ & 2 & I \\
\hline & $\mathrm{N} 54^{\circ} 45.720^{\prime}$ E $17^{\circ} 32.220^{\prime}$ & 3 & II \\
\hline & $\mathrm{N} 54^{\circ} 45.312^{\prime}$ E $17^{\circ} 30.801^{\prime}$ & 2 & II \\
\hline & N $54^{\circ} 45.384^{\prime}$ E $17^{\circ} 30.783^{\prime}$ & 3 & II \\
\hline \multirow[t]{11}{*}{ Padus serotina Ehrh. } & $\mathrm{N} 54^{\circ} 42.884^{\prime}$ E $17^{\circ} 13.765^{\prime}$ & 3 & II \\
\hline & N $54^{\circ} 42.902^{\prime}$ E $17^{\circ} 14.395^{\prime}$ & 1 & III \\
\hline & N $54^{\circ} 42.922^{\prime}$ E $17^{\circ} 13.750^{\prime}$ & 3 & II \\
\hline & N $54^{\circ} 42.993^{\prime}$ E $17^{\circ} 13.712^{\prime}$ & 2 & II \\
\hline & N $54^{\circ} 43.003^{\prime}$ E $17^{\circ} 13.720^{\prime}$ & 2 & II \\
\hline & N $54^{\circ} 45.437^{\prime}$ E $17^{\circ} 32.316^{\prime}$ & 1 & I \\
\hline & 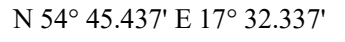 & 3 & I \\
\hline & N $54^{\circ} 45.448^{\prime}$ E $17^{\circ} 32.464^{\prime}$ & 2 & I \\
\hline & $\mathrm{N} 54^{\circ} 45.880^{\prime}$ E $17^{\circ} 31.980^{\prime}$ & 2 & II \\
\hline & $\mathrm{N} 54^{\circ} 43.351^{\prime}$ E $17^{\circ} 32.031^{\prime}$ & 1 & I \\
\hline & N $54^{\circ} 43.321^{\prime}$ E $17^{\circ} 32.110^{\prime}$ & 1 & I \\
\hline
\end{tabular}




\begin{tabular}{|c|c|c|c|}
\hline Species & Locality (GPS) & $\begin{array}{c}\text { Abundance } \\
\text { category }\end{array}$ & Road category \\
\hline \multirow[t]{2}{*}{ Padus serotina Ehrh. } & $\mathrm{N} 54^{\circ} 43.422^{\prime}$ E $17^{\circ} 32.574^{\prime}$ & 1 & I \\
\hline & $\mathrm{N} 54^{\circ} 45.616^{\prime} \mathrm{E} 17^{\circ} 32.395^{\prime}$ & 1 & II \\
\hline \multirow[t]{27}{*}{ Quercus rubra $\mathrm{L}$. } & $\mathrm{N} 54^{\circ} 40.293^{\prime}$ E $17^{\circ} 11.410^{\prime}$ & 2 & IV \\
\hline & $\mathrm{N} 54^{\circ} 40.352^{\prime}$ E $17^{\circ} 11.045^{\prime}$ & 1 & IV \\
\hline & $\mathrm{N} 54^{\circ} 40.380^{\prime}$ E $17^{\circ} 10.929^{\prime}$ & 1 & IV \\
\hline & $\mathrm{N} 54^{\circ} 40.426^{\prime}$ E $17^{\circ} 10.804^{\prime}$ & 2 & IV \\
\hline & $\mathrm{N} 54^{\circ} 40.457^{\prime}$ E $17^{\circ} 10.743^{\prime}$ & 2 & IV \\
\hline & $\mathrm{N} 54^{\circ} 40.469^{\prime}$ E $17^{\circ} 10.826^{\prime}$ & 2 & IV \\
\hline & $\mathrm{N} 54^{\circ} 40.472^{\prime}$ E $17^{\circ} 10.672^{\prime}$ & 2 & IV \\
\hline & $\mathrm{N} 54^{\circ} 40.607^{\prime} \mathrm{E} 17^{\circ} 11.297^{\prime}$ & 2 & IV \\
\hline & $\mathrm{N} 54^{\circ} 40.813^{\prime}$ E $17^{\circ} 09.515^{\prime}$ & 2 & IV \\
\hline & $\mathrm{N} 54^{\circ} 40.918^{\prime} \mathrm{E} 17^{\circ} 09.637^{\prime}$ & 1 & IV \\
\hline & $\mathrm{N} 54^{\circ} 40.982^{\prime}$ E $17^{\circ} 09.537^{\prime}$ & 1 & IV \\
\hline & $\mathrm{N} 54^{\circ} 41.110^{\prime} \mathrm{E} 17^{\circ} 09.594^{\prime}$ & 1 & IV \\
\hline & $\mathrm{N} 54^{\circ} 41.468^{\prime}$ E $17^{\circ} 10.487^{\prime}$ & 1 & IV \\
\hline & $\mathrm{N} 54^{\circ} 41.488^{\prime}$ E $17^{\circ} 10.914^{\prime}$ & 2 & IV \\
\hline & $\mathrm{N} 54^{\circ} 41.491^{\prime}$ E $17^{\circ} 10.834^{\prime}$ & 2 & IV \\
\hline & $\mathrm{N} 54^{\circ} 41.538^{\prime}$ E $17^{\circ} 10.245^{\prime}$ & 1 & IV \\
\hline & $\mathrm{N} 54^{\circ} 45.616^{\prime}$ E $17^{\circ} 32.395^{\prime}$ & 1 & II \\
\hline & $\mathrm{N} 54^{\circ} 45.216^{\prime} \mathrm{E} 17^{\circ} 31.100^{\prime}$ & 1 & II \\
\hline & $\mathrm{N} 54^{\circ} 45.628^{\prime}$ E $17^{\circ} 32.475^{\prime}$ & 3 & II \\
\hline & $\mathrm{N} 54^{\circ} 45.679^{\prime} \mathrm{E} 17^{\circ} 32.340^{\prime}$ & 1 & II \\
\hline & $\mathrm{N} 54^{\circ} 45.499^{\prime}$ E $17^{\circ} 32.487^{\prime}$ & 2 & I \\
\hline & $\mathrm{N} 54^{\circ} 45.478^{\prime}$ E $17^{\circ} 32.445^{\prime}$ & 1 & I \\
\hline & $\mathrm{N} 54^{\circ} 45.441^{\prime}$ E $17^{\circ} 32.466^{\prime}$ & 2 & I \\
\hline & $\mathrm{N} 54^{\circ} 45.453^{\prime}$ E $17^{\circ} 32.525^{\prime}$ & 3 & I \\
\hline & $\mathrm{N} 54^{\circ} 45.463^{\prime}$ E $17^{\circ} 32.540^{\prime}$ & 3 & I \\
\hline & $\mathrm{N} 54^{\circ} 45.473^{\prime}$ E $17^{\circ} 32.685^{\prime}$ & 2 & I \\
\hline & $\mathrm{N} 54^{\circ} 41.944^{\prime}$ E $17^{\circ} 29.338^{\prime}$ & 1 & IV \\
\hline \multirow[t]{6}{*}{ Robinia pseudoacacia L. } & $\mathrm{N} 54^{\circ} 39.327^{\prime}$ E $17^{\circ} 13.442^{\prime}$ & 2 & IV \\
\hline & $\mathrm{N} 54^{\circ} 45.592^{\prime}$ E $17^{\circ} 32.514^{\prime}$ & 1 & I \\
\hline & $\mathrm{N} 54^{\circ} 45.255^{\prime}$ E $17^{\circ} 30.913^{\prime}$ & 2 & I \\
\hline & $\mathrm{N} 54^{\circ} 43.422^{\prime}$ E $17^{\circ} 32.574^{\prime}$ & 3 & I \\
\hline & $\mathrm{N} 54^{\circ} 45.433^{\prime}$ E $17^{\circ} 32.419^{\prime}$ & 1 & I \\
\hline & $\mathrm{N} 54^{\circ} 45.036^{\prime}$ E $17^{\circ} 32.291^{\prime}$ & 1 & I \\
\hline
\end{tabular}




\begin{tabular}{cccc}
\hline \multicolumn{1}{c}{ Species } & Locality (GPS) & $\begin{array}{c}\text { Abundance } \\
\text { category }\end{array}$ & Road category \\
\hline Robinia pseudoacacia L. & $\mathrm{N} 54^{\circ} 45.441^{\prime} \mathrm{E} 17^{\circ} 32.622^{\prime}$ & 1 & $\mathrm{I}$ \\
& $\mathrm{N} 54^{\circ} 45.455^{\prime} \mathrm{E} 17^{\circ} 32.658^{\prime}$ & 1 & $\mathrm{I}$ \\
\hline Acer negundo L. & $\mathrm{N} 54^{\circ} 45.441^{\prime} \mathrm{E} 17^{\circ} 32.466^{\prime}$ & 1 & $\mathrm{I}$ \\
& $\mathrm{N} 54^{\circ} 45.448^{\prime} \mathrm{E} 17^{\circ} 32.464^{\prime}$ & 2 & $\mathrm{I}$ \\
& $\mathrm{N} 54^{\circ} 45.463^{\prime} \mathrm{E} 17^{\circ} 32.540^{\prime}$ & 3 & $\mathrm{I}$ \\
& $\mathrm{N} 54^{\circ} 45.455^{\prime} \mathrm{E} 17^{\circ} 32.658^{\prime}$ & 1 & $\mathrm{I}$ \\
\hline
\end{tabular}

